\section{The Bidayuh Krokong Dialect: To Standardize or not Standardize}

\author{
Jecky Misieng (Corresponding author) \\ Faculty of Language and Communication Studies, Universiti Malaysia Sarawak \\ 94300 Kota Samarahan, Sarawak, Malaysia \\ Tel: 6082-581716 E-mail: mjecky@unimas.my
}

Received: November 26, 2016 Accepted: January 9, 2017 Published: January 11, 2017

doi:10.5296/elr.v3i1.10585ＵRL: http://dx.doi.org/10.5296/elr.v3i1.10585

\begin{abstract}
The intricacies of language require all language scientists to be thorough and methodical in doing their analyses. This need is even more critical for the Bidayuh languages when there is a lot of on-going effort to preserve the language by various groups both from 21 the people as well those from outside. Standardization and the teaching of the language in schools are among the top suggestions being explored. One of the disadvantages of standardizing a language is the danger of making the many different varieties to die out among the speakers. A closer look at one Jagoi sub-dialect commonly referred to as the Krokong dialect in comparison to other sub-dialects and dialects from other clusters illustrate some of the differences in pronunciation that can be found which highlights the need to help preserve if not all but most of the major varieties.
\end{abstract}

Keywords: Language, Bidayuh, Krokong, Standardization, Dialect, Phonetic, Phonology, Morpheme structure constraints, Consonants, Vowels

\section{Introduction}

Bidayuh or Land Dayak is one of the many races that make up the multi-racial country of Malaysia. This tribal group and their kin can be found throughout the island of Borneo. However, the Malaysian Bidayuh resides predominantly in the state of Sarawak on the northern portion of the island. The name, Bidayuh, is often used synonymously to refer to the language spoken by the people. " $\mathrm{Bi}$-" is a prefix when attached to nouns in the language carries the meaning of the one who is of and "dayuh" is actually a variation of the word "doyoh" [djjoh] which means land. A literal translation of the name Bidayuh is People of the Land. As for the name Land Dayak, Dayak (sometimes misspelled as Dyak) which is pronounced with a glottal stop [daja?] in the final consonant by most native speakers of 
Bidayuh simply means people. Hence, Bidayuh or Land Dayak carries the same meaning which is People of the Land. However, the former is preferred nowadays for various reasons including political reasons. Some people would confuse Land Dayak with another group of people living in the same sate known as the Ibans who were formerly referred to as the Sea Dayaks.

Over the years until the beginning of the last decade limited contact among the different villages especially those very far apart from each other has brought about different varieties of the Bidayuh language being spoken. As a result, there are now at least four major varieties that have been mentioned in various studies about the language. Even though some studies mentioned five major dialects of Bidayuh which include Salako-Lara (Rensch, Rensch, Jonas Noeb \& Robert Sulis Ridu, 2012; Collins, 1993), Salako-Lara varieties are actually closer to the Malay language than any of the Bidayuh varieties. Hudson (1970) correctly classified Salako as a Malayic Dayak language and the observation is supported by Rensch et al. (2012) and Chan (2002). The Salako group is placed under Bidayuh more for socio-political reasons rather than linguistic interests. Rensch (2008) provided a clearer picture of the major groupings found in Sarawak by describing them as four clusters namely Bukar- Sadung, Biatah-Penrissen-Lower Padawan, Tringgus-Sembaan-Upper Padawan and the Singgai-Jagoi.

These four main groupings can be sub-divided into major dialects. For example, in the Bukar-Sadung cluster, there are the the Bukar and the Sadong dialects, while the Biatah and the Bianah belong to the Penrissen-Lower Padawan cluster. The Singgai, the Bro'ih and the Jagoi dialects come under the Singgai-Jagoi cluster. Each of these major dialects in turn have their own sub-dialects which may be defined by geographical boundaries. It is also worth noting that some slight variations to each of these sub-dialects can also be perceived by native speakers so much so that it is possible to identify which village a particular Bidayuh person is from. These slight variations across villages have made it difficult to classify and group the Bidayuh language varieties there are in existence. A study done by Rensch and the SIL International team estimated the number of dialects as 25 (Rensch, Rensch, Jonas Noeb \& Robert Sulis Ridu, 2012). On the other hand, an earlier study mentioned that there are 25 Bidayuh groups instead of dialects (Chang, 2002). This confusion can clearly be discerned from the way the names of these sub-dialectsub-dialects are derived from. Some researchers labelled the different varieties using geographical regions such as Penrissen or Bau, others are more specific by using individual villages such as Grogo or Tringgus as their dialect labels (Chang, 2012; Rensch et al., 2012) and some used land features like mountains with names like Bibəngoh, Bisəpug and Serombu from the Bəngoh, the Səpug and the Serombu mountains respectively (Kroeger, 1994). but most combined the names of the major dialect variety with geographical locations such Bau Jagoi or Penrissen Biatah. Hence, the incongruence in the numbers of varieties reported.

Under the Jagoi [dzagji] sub-dialect and the Singgai [singar] sub-dialect. The mutual intelligibility between the Jagoi variety and the Singgai sub-dialect is relatively high but most Singgai-Jagoi speakers find it almost impossible to communicate with speakers of the Bukar-Sadong dialects. As a result, many speakers of these different clusters often resort to another language such as Malay or English to communicate with one another. It is also not 


\section{Macrothink \\ Education and Linguistics Research \\ ISSN 2377-1356 \\ 2017, Vol. 3, No. 1}

surprising to find two Bidayuhs speaking in Iban with one another due to the extreme differences in their dialects.

For the purpose of this treatise, the variety that will be discussed here is the Jagoi variety specifically from the Krokong district of Bau. As was noted earlier, a Bidayuh from this area can be identified by the slight variation in his speech which is quite distinct from the other Jagoi varieties. However, in recent years, this slight variation is fast disappearing due to more contact between new generations of speakers with those of other Jagoi sub-dialect.

Nevertheless, most dialects are distinguishable from one variety to another based on the pronunciation, lexical and semantic differences. These differences are more obvious when comparing varieties from two different clusters. However, when they come from the same cluster, the dialects share more than 50 percent similarities in all the three aspects. A closer look at one Jagoi sub-dialect commonly referred to as the Krokong dialect and comparing it to other sub-dialect and dialects from other clusters illustrate some of these differences.

Pronunciation differences between the Bau-Jagoi (Krokong) and Singgai sub-dialects

\begin{tabular}{|c|c|c|c|}
\hline \multicolumn{2}{|c|}{ Jagoi (Krokong) } & $\underline{\text { Singgai }}$ & $\underline{\text { Gloss }}$ \\
\hline sindo' & [Sindo?] & [SIndə?] & mother \\
\hline sama' & [ & [ & father \\
\hline limoh & [rimoh] & [riməh] & five \\
\hline
\end{tabular}

Differences in lexical items may distinguish between the Bau (Krokong) and Bukar- Sadong

\begin{tabular}{|c|c|c|c|c|}
\hline \multicolumn{2}{|c|}{ Bau (Krokong) } & \multicolumn{2}{|c|}{ Bukar-Sadong } & Gloss \\
\hline tubi' & [tubi?] & sungkoi & [sunkJi] & boiled rice \\
\hline sama' & [ & amang & [aman] & father \\
\hline sindo' & [Sindo?] & ando' & [andə?] & mother \\
\hline $\operatorname{man}$ & [man] & ma'an & [ma?an] & eat \\
\hline oku’ & [jkv?] & aku' & [aku?] & I, me \\
\hline ingan & [Inan] & kinden & [kIndən] & you $(p l)$ \\
\hline mu'as & [mulaf] & engkarai & [ə⿹karaı] & mourning \\
\hline
\end{tabular}

Lexical differences can also distinguish between the subvarieties. 


\section{Macrothink}

Education and Linguistics Research

ISSN 2377-1356 2017, Vol. 3, No. 1

Bau-Jagoi (Krokong)

$\underline{\text { Singgai }}$

$\underline{\text { Gloss }}$

bori [bors $]$

romin [romin]

house

pas [pa $]$

tupia [topiə]

squirrel

Semantic differences do occur as well to distinguish the major varieties of Bidayuh. Similar words used carry different meaning across the different varieties.

\section{$\underline{\text { Bau (Krokong) }}$}

to feed

\section{Bukar-Sadong}

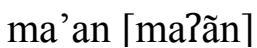$$
\text { to feed }
$$

to eat

\section{Consonants}

In general, the Bidayuh language has 18 consonants. The Krokong variety employs all

18 of these consonants. The language uses mainly pulmonic airstream mechanism for the articulation of its consonants. There are seven plosives and four nasals as shown in Table 1 below.

Table 1. Consonants of Krokong Dialect

\begin{tabular}{|c|c|c|c|c|c|c|c|}
\hline \multicolumn{2}{|c|}{ Place Manner } & Bilabial & Alveolar & Palato- alveolar & Labial- & Velar & Glottal \\
\hline \multirow[t]{2}{*}{ Stops } & Voiceless & $\mathrm{p}$ & t & & & $\mathrm{k}$ & ? \\
\hline & Voiced & $b(6)$ & $d(d)$ & & & $g(g)$ & \\
\hline \multicolumn{2}{|c|}{ Nasals } & $\mathrm{m}$ & $\mathrm{n}$ & $n$ & & $\eta$ & \\
\hline \multicolumn{2}{|c|}{ Tap or Flap } & & $r$ & & & & \\
\hline \multicolumn{2}{|c|}{ Fricatives } & & & $\int$ & & & h \\
\hline \multicolumn{2}{|c|}{ (Voiceless) } & & & & & & \\
\hline \multicolumn{2}{|c|}{ Affricates } & & & ds & & & \\
\hline \multicolumn{2}{|c|}{ (Voiced) } & & & & & & \\
\hline \multicolumn{2}{|c|}{ Approximants } & & & j & $\mathrm{w}$ & & \\
\hline
\end{tabular}




\subsection{Plosives}

\subsubsection{Bilabials}

Bidayuh has voiceless and voiced bilabial plosives [p] and [b] respectively. They form a contrast in words shown below.

In the beginning of words such as:

$\begin{array}{lll}\text { pisa' } & \text { [pIfa? } & \text { bamboo } \\ \text { bisa' } & \text { [bIfa? } & \text { wet }\end{array}$

In medial position in words such as:
sopa' [ [כра?]
cut (noun)
soba' [ [joba?]
downstream

In word final position in words such as:

totap $[$ totap] for sure
totab [totab]

The voiced bilabial plosive of Bidayuh, particularly the Jagoi variety is slightly implosive in its articulation at the end of words. This is done by drawing in air trapped in the mouth in towards the back of the mouth by holding your breath before releasing the lip closure. Thus, in the narrow transcription of the word for 'totab' above, it would be more accurate to employ the voiced bilabial implosive [ 6 ]. Thus, the word is transcribed as [tota6]. This feature is predictable in that it occurs only at the end of words. This is important to note for those who want to learn to speak Bidayuh Jagoi like a native speaker. Most foreign speakers of the language variety can be detected in the way that they articulate the voiced bilabial plosive at the end of words where all fluent Bidayuh Jagoi speakers would use the implosive instead.

\subsubsection{Alveolars}

In Bidayuh, the language also has voiceless and voiced alveolar plosives [t] and [d] respectively. They form a contrast in words shown below. 
In the beginning of words such as:

todang [todajk] corpse

dodang [dodajk] husk

In medial position in words such as:

poti [potil chest (box)

podi [podr] paddy

In word final position in words such as:

$\begin{array}{lll}\text { pat } & \text { [pat] } & \text { four } \\ \text { pad } & \text { [pad }] & \text { fall over }\end{array}$

As in the bilabial plosive above, the voiced alveolar plosive is slightly implosive in its articulation at the end of words. The trapped air is sucked into the back of the mouth blocked by the alveolar ridge before final release. The narrow transcription for the word fall over above is [pad].

\subsubsection{Velars}

The language also employs voiceless and voiced velar plosives $[\mathrm{k}]$ and $[\mathrm{g}]$ respectively. They form a contrast in words shown below.

In the beginning of words such as:

kondang [kJndayk] magpie

gondang [gondayk] drum

In medial position in words such as:

toke [toke] shopowner

toge $[\operatorname{tog} \varepsilon]$ bean sprouts

In word final position in words such as: 


\section{Macrothink

rorak [rorak] torn

rorag [rorag] landslide

The voiced velar plosive is also slightly implosive in its articulation at the end of words just like the bilabial and the alveolar plosives. This is done by sucking in trapped air towards the back of the mouth by holding your breath with the velic closure before releasing it. The narrow transcription for the word landslide above is [rorag].

\subsubsection{Glottal}

The language has a full glottal plosive or stop [?]. A full glottal stop is almost always voiceless as its production involves abruptly stopping the airflow from the lungs by the vocal chords in the larynx and effectively preventing sound from continuing (Ladefoged \& Maddieson, 1996). Just like in many languages and Bidayuh do not employ voiced glottal plosives (Garellek, 2013).

\section{Word Initial Position}

In the beginning of words, it occurs when the word begins with a vowel just like in

English.

'itih [?Itth] this

'aat [Ra:t] root

'oku' [?כkv?] I, me

'umud [?umud] $\quad$ shoots of tropical plants

\section{Medial Position}

In this position, the glottal stop contrast not only with other consonants but also in words with long vowels such as:

ba'at [ba?at] boundary

baat [ba:t] heavy

It contrasts with the voiceless velar plosive $[\mathrm{k}]$ in words such as:

bo'os [bo?J] $]$ asleep

bokos [bokJ] ropes 


\section{Macrothink

In words with the labial-velar approximant (glide) [w] such as:

su'an [SoPant] to blow your nose

suan [Sowant] to hide

Word Final Position

It forms a contrast with the voiceless velar plosive $[\mathrm{k}]$ in the final position in words such as:

jora' [dzэra?] difficult

jorak [dgrak] deer

In words with the glottal fricative [h] such as:

tanda' [tanda?] dance

tandah [tandah] let it be

\subsection{Nasals}

Like most Jagoi nasals, Krokong dialect nasals are unlike nasals found in other languages such as English or Malay. There are reasons to believe that it has several types of nasals unique to this dialect of Bidayuh.

\subsubsection{Bilabial Nasals}

Word Initial Position

Consider the examples below:

(i) ma' [ma?] dad

(ii ma' [mba?] don't

(iii) aam [a:mp expression to denote disappearance

In (i) the vowel that follows the nasal consonant is nasalized whereas in (ii) it is not. It sounds like a co-articulation of the bilabial nasal and the voiced bilabial plosive [b]. This occurs in the beginning of words as well as word medial position. However, it is apparent that some vowels are not nasalized in spite the presence of the nasal in certain environments. If this is true and the sound is in fact a single segment, we can state that the nasal behaves in such a manner when vowels following it are not nasalized. We can also see that vowels are not nasalized when the nasal occurs at the end of words as shown in (iii). Not only that, the nasal itself loses its voicing quality to reveal a sound similar to the articulation of the unreleased voiceless bilabial plosive [ $\vec{p}]$. This was also observed by other Bidayuh language researchers 
(Court, 1967, 1970; Kroeger, 1994) but they described the sound feature as occurring before the nasal and not the missing voicing quality of the nasal. Scott (1994) described the sound produced as a result of an articulation following a non-nasal vowel, which in turn occurs when the preceding is a non-nasal consonant. The example given was in the Upper Padawan Biatah dialect for the word 'mendam' [məndaPm] with the diacritic ' $\mathrm{P}$ ' to symbolize the sound. However, in reality the sound that is heard is actually an unreleased plosive that occurs with all the nasal consonants of Bidayuh when it ends a word with the exception of the palatal nasal.

Non-native speakers of Bidayuh find these unique features quite cumbersome to master. Therefore, they often missed the distinction shown in (ii) and (iii).

There are other words which seem to support this claim.

\begin{tabular}{|c|c|c|}
\hline mit & [mbit] & to take \\
\hline moh & {$[\mathrm{mbJh}]$} & done \\
\hline
\end{tabular}

There are words in this dialect that have nasalized vowels following the nasal even after a non-nasal consonant. In the example below, the other consonant is flap or a tap. Note that the nasalized vowels are shown by the diacritic [ ] on top of the vowel.

milih [mirih $]$ to buy

Compare this to a loan word from Malay which does not have nasalization in the second vowel after the non-nasal consonant.

milih [mirih] to choose

In the Bukar Sadong dialect, a similar occurrence can be observed for the bilabial nasal as shown in the word below:

mu'as [mũãs] to cry

\section{Medial Position}

The sound also occurs in word medial position. Note that the nasalized vowels are shown by the diacritic [ ${ }^{\sim}$ ] on top of the vowel.

mamuh [mamũh] to bathe 


$\begin{array}{lll}\text { limoh } & \text { [rımว̃h }] & \text { five } \\ \text { pimoh } & {[\text { pımว̃h }]} & \text { dream } \\ \text { samah } & \text { [Jamãh }] & \text { the same }\end{array}$

Consider these examples where all the vowels following the nasal are not nasalized.

$\begin{array}{lll}\text { sambal } & {[\text { Jambar }]} & \text { paste } \\ \text { somba } & {[\text { Jjmba }]} & \text { uncle (parents' older brother) } \\ \text { sambuh } & {[\text { Jamboh }]} & \text { arrogant }\end{array}$

It seems to support that this nasal has two components $/ \mathrm{m} /$ and $/ \mathrm{b} /$ and the examples above show that it can begin a word as a single entity.

\section{Word Final Position}

The sound also occurs at word final position or at the end of words. Note also that the vowels are not nasalized.

$\begin{array}{lll}\text { iam } & \text { [iamp] } & \text { hour } \\ \text { uwom } & {[\text { Uwomp }]} & \text { pangolin } \\ \text { kuwom } & {[\text { kuwomp }]} & \text { capsized } \\ \text { giyam } & {[\text { gijamp }]} & \text { rapids } \\ \text { ngutuom } & {[\text { yutowəmp }]} & \text { to harvest }\end{array}$

It seems that the nasal is produced together with the unreleased voiceless bilabial plosive [p] as shown in the examples above. However, it is more accurate to state that the nasal becomes voiceless in word final position.

Consider these examples where all the vowels preceding the nasal are nasalize

\begin{tabular}{|c|c|c|}
\hline nguruom & 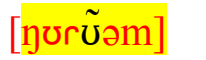 & to soak \\
\hline singarom & 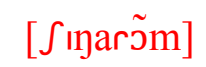 & at night \\
\hline nguram & [yurãm] & to eat with dipping sauce \\
\hline Sibum & [ sibũm] & Name of a Bidayuh man \\
\hline
\end{tabular}




\section{Macrothink \\ Education and Linguistics Research \\ ISSN 2377-1356 \\ 2017, Vol. 3, No. 1}

Vowels in this Bidayuh dialect become nasalized when it is preceded and followed by nasals. The examples below illustrate this language phenomenon.

\begin{tabular}{|c|c|c|}
\hline mem & {$[\mathrm{m} \tilde{\varepsilon} \mathrm{m}]$} & a white woman \\
\hline nyam & [nãm] & serve you right \\
\hline dumam & [dumãm] & a type of fern called Lycopodium cernuum \\
\hline sinyum & 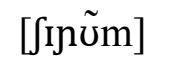 & to smile \\
\hline
\end{tabular}

\subsubsection{Alveolar Nasals}

Just as it is with the bilabial nasal, the alveolar nasal has the two sounds which contrast with each other due to the presence or absence of the vowel nasalization. Consider these examples.

$\begin{array}{lll}\text { tanda' } & {[\operatorname{tanda}]} & \text { dance } \\ \text { tana' } & {[\text { tanã? }]} & \text { soil }\end{array}$

\section{Word Initial Position}

In the beginning of words, a co-articulation of the alveolar nasal and the voiced alveolar plosive [d] occurs just like the bilabial nasal with its bilabial plosive. This is also resulting in the vowels being non-nasalized and it can begin a word as a single consonant. Consider these examples:

$\begin{array}{lll}\text { no' } & {[\text { ndo? }]} & \text { mom } \\ \text { nai } & {[\text { ndar }]} & \text { to make } \\ \text { nuok } & {[\text { ndowok }]} & \text { to drink }\end{array}$

Compare the nasal occurring in words as shown below where the vowels are nasalized.

\begin{tabular}{|c|c|c|}
\hline nah & [nãh] & take it \\
\hline nowu' & [ñ̃̃)?] & to cut grass \\
\hline noh & [nכ̃h] & that \\
\hline
\end{tabular}

This nasal also behaves like the bilabial nasal where it influences vowels even after the vowels are preceded by a non-nasal consonant. Consider the example below with the other consonant being a flap or a tap:

nalu [nãrõ $] \quad$ to scare 


\section{Medial Position}

The sound also occurs in word medial position with co-articulation with the voiced alveolar plosive in words such as:

$\begin{array}{lll}\text { ondu } & {[\text { ondu }]} & \text { day } \\ \text { pondai } & {[\text { pondar }]} & \text { smart } \\ \text { sonduk } & {[\text { [jnduk }]} & \text { spoon } \\ \text { banduok } & {[\text { bandojk }]} & \text { tapioca }\end{array}$

Consider these examples where all the vowels following the nasal are nasalized.

$\begin{array}{lll}\text { oni } & {[\text { onĩ }]} & \text { what } \\ \text { guni } & {[\text { gonĩ }]} & \text { a sack } \\ \text { ponu } & {[\text { ponũ }]} & \text { to walk } \\ \text { bisina } & {[\text { bı } \text { inã }]} & \text { Chinese }\end{array}$

\section{Word Final Position}

The alveolar nasal also becomes voiceless in word final position. Note also that the vowels are not nasalized and the sound is symbolized in the examples below with the unreleased voiceless alveolar plosive $(\mathrm{t})$. This loss of nasality may be due to the assimilation with the preceding non-nasal consonant as shown in the examples below.

\begin{tabular}{|c|c|c|}
\hline aan & [a:nt] & I don't know \\
\hline tuan & [tuwant] & a white man \\
\hline pi'in & [pi?int] & water \\
\hline ijan & [Idgant] & rain \\
\hline so'on & 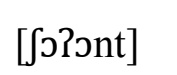 & can \\
\hline dowon & [dכwont] & leaf \\
\hline
\end{tabular}

However, there is one word where the vowel that precedes this nasal is nasalized but the consonant before it is a non-nasal as shown below.

kimaran [kımarãn] a container to store rice 


\section{Macrothink \\ Education and Linguistics Research \\ ISSN 2377-1356 2017, Vol. 3, No. 1}

Like the other Bidayuh nasals, vowels become nasalized when it is preceded and followed by nasals. The examples below illustrate this.

\begin{tabular}{|c|c|c|}
\hline ngin & [nIn] & to give \\
\hline muun & [mũ:n] & to go down \\
\hline angan & [ayãn] & insecure \\
\hline somon & {$\left[\int \mathfrak{m} \tilde{\mathrm{n}}\right]$} & to babysit \\
\hline punuon & 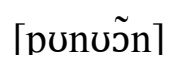 & a mishap due to missing a meal \\
\hline tuman & [tumãn] & to ambush \\
\hline
\end{tabular}

\subsubsection{Palatal Nasals}

Word Initial Position

Unlike the bilabial and the alveolar nasals, there is no co-articulation because this consonant is an approximant and not a plosive. However, it can begin a word in all Jagoi dialects including the Krokong variety. Consider the following examples:

\begin{tabular}{|c|c|c|}
\hline nyog & 「nว़̣ๆ & to dip(as in dipping in sauce) \\
\hline nyi'it & [ni?it] & to sew \\
\hline nyagam & [nãgamp] & to catch \\
\hline nyok & [nok] & footprints \\
\hline
\end{tabular}

Just as in the case of the two previous nasals, we also have words that have nasalized vowels following the nasal even after another consonant. In the example below, the other consonant is a glottal stop.

nya'a [nãrã] people

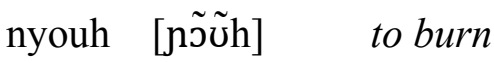




\section{Macrothink

Medial Position

The sound also occurs in word medial position in words such as:

\begin{tabular}{|c|c|}
\hline inyuo' & [ıกั̃ว] \\
\hline bonyih & [bənıh] \\
\hline onyu' & [рэли̃?] \\
\hline
\end{tabular}

Nasalized vowels following the palatal nasal in word medial position are shown below.

$\begin{array}{lll}\text { kunyi } & {[\text { kujĩ }]} & \text { sour } \\ \text { sunyi } & {\left[\int \tilde{j} \tilde{I}\right]} & \text { lonely }\end{array}$

Vowels also become nasalized when they are preceded by this nasal and followed by other nasals. Consider these examples.

bironying [birэñ̃y] heaty

kunyong [kujõ̃ $]$ nun

The palatal nasal is not found at the end of words in this dialect of Bidayuh.

\subsubsection{Velar Nasals}

Word Initial Position

In the beginning of words, consider these examples below. There is no co-articulation for this nasal in the word initial position.

\begin{tabular}{|c|c|c|}
\hline ngin & {$[\eta \tilde{n}]$} & to give \\
\hline nguu & 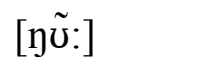 & to sweep \\
\hline ngoon & 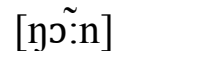 & aware \\
\hline ngodah & 「ñ̃dahๆ & naughtv \\
\hline ngituong & [ỹ̃tuwoyk] & to narrate \\
\hline
\end{tabular}

We also have words that have nasalized vowels following this nasal even after another consonant. In this case, the example has the flap or tap.

ngulu [yũrõ] to accompany 


\section{Macrothink \\ Education and Linguistics Research \\ ISSN 2377-1356 \\ 2017, Vol. 3, No. 1}

Medial Position

In word medial position, the velar nasal of the Jagoi dialect occurs as a co-articulation with its voiced plosive counterpart just like the bilabial and the alveolar nasals. It can be observed in the examples shown below:

$\begin{array}{lll}\begin{array}{c}\text { tongga } \\ \text { nangga }\end{array} & \begin{array}{l}\text { [tonga } \\ {[\text { nanga? }]}\end{array} & \begin{array}{l}\text { visible } \\ \text { to support like a ladder }\end{array} \\ \text { ningga’ } & {[\text { ninga? }]} & \text { look } \\ \text { tonggos } & {[\text { tojgJ] }]} & \text { name of a river fish }\end{array}$

Consider these examples where all the vowels following the nasal are nasalized. This occurs when there is no co-articulation.

\begin{tabular}{|c|c|c|}
\hline bunga & 「bungã $\rceil$ & a flower \\
\hline pongu & 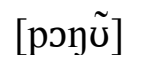 & an insect which has a pungent odour \\
\hline simongi & 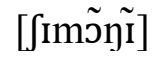 & soul \\
\hline
\end{tabular}

\section{Word Final Position}

The velar nasal also becomes voiceless in word final position. Note also that the vowels are not nasalized just like the bilabial and alveolar nasals which are symbolized as the unreleased voiceless velar nasal $(\mathrm{k})$ here.

$\begin{array}{lll}\text { tung } & {[\text { tonk }]} & \text { to light a fire } \\ \text { taang } & {[\text { ta: } \mathrm{jk}]} & \text { a cave } \\ \text { kuyong } & {[\mathrm{k} \text { kjoyk }]} & \text { lipstick } \\ \text { kombing } & {[\mathrm{k} \text { ombink }]} & \text { goat }\end{array}$

Consider these examples where all the vowels preceding the nasal are nasalized.

noyung [njjũ̃] parents'older sister

seng $\quad\left[\int \tilde{\varepsilon} \eta\right] \quad$ zinc roofing

nyayang [nãjãy] to love 


\section{Macrothink \\ Education and Linguistics Research \\ ISSN 2377-1356 \\ 2017, Vol. 3, No. 1}

\subsubsection{Grammatical Functions of Krokong Nasals}

The nasals of Bidayuh have the special property of being used as a bound morpheme. When attached to nouns as a prefix they form verbs. For example:

\begin{tabular}{|c|c|c|c|c|c|}
\hline \multicolumn{3}{|c|}{ Gloss } & \multicolumn{2}{|l|}{ Verb } & \multirow{2}{*}{$\begin{array}{l}\text { Gloss } \\
\text { to whack }\end{array}$} \\
\hline posut & {$\left[\mathrm{pJ} \int \mathrm{vt}\right]$} & a whack & mosut & [mosut] & \\
\hline botah & [botah] & broken & motah & [motah] & to break \\
\hline tomi & {$[\mathrm{t} J \mathrm{mI}]$} & a sojourner & nomi & [nכmI] & to sojourn \\
\hline tuboh & [tuboh] & a poisonous plant & nuboh & [nubsh] & to fish with poison \\
\hline sobu & {$\left[\int \jmath b v\right]$} & weeding & nyobu & [nobv] & to remove weed \\
\hline ji'it & [dzIIIt] & sewing & nyi'it & [nI?It] & to sew \\
\hline kojit & {$[\mathrm{kJd} z \mathrm{It}]$} & an ear & ngojit & [yJdzIt $]$ & to hear \\
\hline obot & [?obot] & a lock & ngobot & [n’obot] & to lock \\
\hline
\end{tabular}

In the above examples, it is shown that the prefixation of nouns to form verbs is quite predictable. The bilabial nasal [m] will replace the bilabial stops [p] and [b] while the alveolar nasal [n] will replace the alveolar stop [t]. The palatal nasal [n], on the other hand, will replace the fricative [S] as well as the affricate [d3] and in the beginning of noun words to form verbs. The velar nasal [ $\mathrm{g}$ ] will replace the velar stop [g] or the glottal stop [?] in the beginning of noun words to form verbs. For a more exhaustive explanation of how nasals behave in Bidayuh, refer to Rensch's (2006) Nasality in Bidayuh phonology.

\subsection{Tap/Flap}

This dialect of Bidayuh employs an alveolar tap or flap [r]. It is often mistaken for an alveolar trill [r] or the lateral approximant [1]. Native speakers of Bidayuh would notice intuitively that it is neither one. It is apparent when Bidayuh speakers pronounce loan words containing the two sounds, they would substitute them with the tap. Consider the examples below:

\begin{tabular}{|c|c|c|c|c|}
\hline Malay & & Bida & & Gloss \\
\hline lampu & [lampu] & lapu & [rapv] & lamp \\
\hline harap & [haRap] & arap & [arap] & hope \\
\hline
\end{tabular}

The inability to articulate the Bidayuh tap or flap correctly or substituting them with the trill or the lateral is usually attributed to a child who is just starting to learn to speak the language 


\section{Macrothink \\ Education and Linguistics Research \\ ISSN 2377-1356 \\ 2017, Vol. 3, No. 1}

or a non-native speaker attempting to communicate in the Bidayuh dialect. Compared to the trill or the lateral, the tap is not an easy sound to make as it involves flicking or tapping very briefly the tip of the tongue against the roof of the mouth.

In the beginning of words:

\begin{tabular}{|c|c|c|}
\hline rap & [rap] & an expression to denote fire being extinguished \\
\hline rubuh & [rubuh] & destroyed \\
\hline $\begin{array}{l}\text { leh } \\
\text { lomak }\end{array}$ & $\begin{array}{l}\text { [reh] } \\
{[\text { rombak] }}\end{array}$ & $\begin{array}{l}\text { a particle expression similar to the Malay 'lah' } \\
\text { fatty tissue }\end{array}$ \\
\hline lah & [rorah] & tired \\
\hline
\end{tabular}

In medial position in words such as:

$\begin{array}{lcc}\text { aruo' } & {[\text { arvo? }]} & \text { not yet } \\ \text { biru } & {[\text { birv }]} & \text { blue and green } \\ \text { porih } & {[\text { porih }]} & \text { taboo } \\ \text { sorai } & {[\text { Jjrar }]} & \text { lemon grass } \\ \text { bora' } & {[\text { bora? }]} & \text { lack of sleep }\end{array}$

In word final position in words such as:

$\begin{array}{lll}\text { bar } & \text { 「barl } & \text { A river snakehead fish } \\ \text { bukar } & \text { [bokar }] & \text { to take out } \\ \text { kol } \quad[\mathrm{kJr}] & \text { a lump } \\ \text { sakir } & \text { [Jakır }] & \text { a cup } \\ \text { takal } & \text { [takar] } & \text { when }\end{array}$

\subsection{Fricatives}

One of the only two fricatives, evident in Bidayuh is the palato-alveolar or alveo- palatal fricative. Only the voiceless one is employed. Just like the tap or flap described previously, there is a tendency to confuse this sound with another seemingly but a totally different sound which is the voiceless alveolar fricative [s]. Most native speakers of Bidayuh find it difficult to articulate this alveolar fricative when speaking in a foreign language that carries this sound. They often substitute it with the palato-alveolar fricative [J] which they do have in their language inventory. As often observed by their fellow Malaysian countrymen, the Bidayuh speakers would often substitute the alveolar fricative found in many Malay words with the palate-alveolar counterpart. Consider the examples below. 


$\begin{array}{lll}\text { Malay } & \underline{\text { Interlanguage Articulation }} & \text { Gloss } \\ \text { suka } & {\left[\int \mathrm{vka}\right]} & \text { like } \\ \text { rusa } & {\left[\mathrm{rv} \int \mathrm{a} ?\right]} & \text { a deer } \\ \text { bas } & {[\mathrm{ba}]} & \text { a bus }\end{array}$

The same substitution occurs when speaking in English as well. Consider the following loan words as examples:

$\underline{\text { English } \quad \underline{B i d a y u h}}$

sorry [jכrI]

Lisa [rI $\quad$ a $]$

police [porif]

The palato-alveolar fricative is also used to substitute a missing consonant in the Bidayuh phonology which is the voiceless affricate [ $\mathrm{t}]$ ] as shown in the example of loan words taken from the English language below.

English $\quad \underline{B i d a y u h}$

chocolate [Jjkret]

ketchup [kIJap]

peach [pIS]

However, the palato-alveolar fricative is a very productive sound as it is found in many words of Bidayuh as shown by the examples in the Krokong dialect below

In the beginning of words:

$\begin{array}{lll}\text { sap } & {[\text { Jap }]} & \text { taste } \\ \text { sumbu } & {\left[\int \mathrm{Jumbu}\right]} & \text { wick } \\ \text { sarah } & {[\text { Jarah }]} & \text { chest (box) } \\ \text { sindie' } & {[\text { Jindije? }]} & \text { since when }\end{array}$


In medial position in words such as:

\begin{tabular}{|c|c|c|}
\hline bisu' & [bIfv?] & $d u m b$ \\
\hline posih & [p于fih] & drizzling \\
\hline nosa' & [ñfa?] & to stopover \\
\hline mosia' & [mગ $\mathrm{I} \varepsilon \varepsilon ?]$ & sweet \\
\hline
\end{tabular}

In word final position in words such as:

$\begin{array}{lll}\text { nyas } & {[\mathrm{na}]} & \text { an expression to show anger } \\ \text { tukas } & {\left[\mathrm{tuka} \int\right]} & \text { broke apart } \\ \text { kos } & {[\mathrm{kJ}]} & \text { turn } \\ \text { pirokis } & {[\mathrm{pIrJkI}]} & \text { boil (skin disease) } \\ \text { rosih } & {\left[\mathrm{rJ} \int \mathrm{Ih}\right]} & \text { fishy odour }\end{array}$

\subsection{Affricates}

There is only one affricate in this variety of Bidayuh. The voiced palato-alveolar or alveo-palatal affricate. It occurs only in the word initial and word medial positions.

In the beginning of words:

\begin{tabular}{|c|c|c|}
\hline ja' & $\lceil$ dza?ๆ & let us or let's \\
\hline juu' & [dzv:?] & soup \\
\hline jook & [dzo:k & had enough \\
\hline ji'it & [dzIRIt] & sewing (n) \\
\hline
\end{tabular}

In medial position in words such as:

$\begin{array}{lll}\text { iju } & {[\text { Idzo }]} & \text { fish trap } \\ \text { uja' } & \text { [Jdza? }] & \text { spit }(n) \\ \text { kojit } & {[\text { kJdzIt }]} & \text { ear } \\ \text { bojuh } & {[\text { bodzoh }]} & \text { shirt }\end{array}$




\section{Macrothink

\subsection{Approximants}

There are two approximants in the language.

\subsubsection{Palatals}

The palatal approximant [j] is one of the two approximants available in the sound system of the Krokong dialect. It seems to occur only in the word initial and word medial positions. However, the articulation of the sound at the end of words may also be the same sound signified by the high front vowel [I] as part of a diphthong.

In the beginning of words:

$\begin{array}{lll}\text { ye' } & {[j \varepsilon ?]} & \text { going to } \\ \text { yoh } & {[\mathrm{j} \mathrm{jh}]} & \text { short for yes or you }\end{array}$

In medial position in words such as:

$\begin{array}{lll}\text { ayak } & {[\text { ajak }]} & \text { water piping system made of split bamboos } \\ \text { oyag } & {[\text { jjag] }} & \text { sifting basket } \\ \text { ayuh } & {[\text { ajoh }]} & \text { big } \\ \text { ayuo } & {[\text { ajoə] }} & \text { they/them } \\ \text { oyuo, } & {[\text { jjoə? }]} & \text { a pig } \\ \text { koyuh } & {[\text { kjjoh }]} & \text { wood } \\ \text { mayuh } & {[\text { mãjoh }]} & \text { skinny } \\ \text { siyuok } & {[\text { rijojk }]} & \text { a chicken }\end{array}$

\subsubsection{Labial-velars}

Another approximant found in the language is the labial-velar approximant [w]. The examples below illustrate the productiveness of the sound in the language.

In the beginning of words:

watki [watkI] how 
watitih [watıtıh] like this

watinoh [watınoh] like that

In medial position in words such as:

$\begin{array}{lll}\text { awah } & \text { [awah }] & \text { sitting room } \\ \text { juwah } & {[\text { dzowah }]} & \text { backpacking basket } \\ \text { sowa' } & {[\text { [jwa? }]} & \text { year } \\ \text { kawin } & {[\text { kawint }]} & \text { marry } \\ \text { tawas } & {[\text { tawa }]} & \text { cleared }\end{array}$

In word final position in words such as:

$\begin{array}{lll}\text { obow } & \text { [obow }] & \text { cool down } \\ \text { Kulow } & {[\text { korow }]} & \text { Name of famous historical Bidayuh leader } \\ \text { Kapow } & {[\text { kapow }]} & \text { Name of famous limestone caves in Bau } \\ \text { jombow } & \text { [d3ombow }] & \text { a big knife }\end{array}$

\section{Vowels}

3.1 Monophthongs and Diphthongs of the Krokong dialect

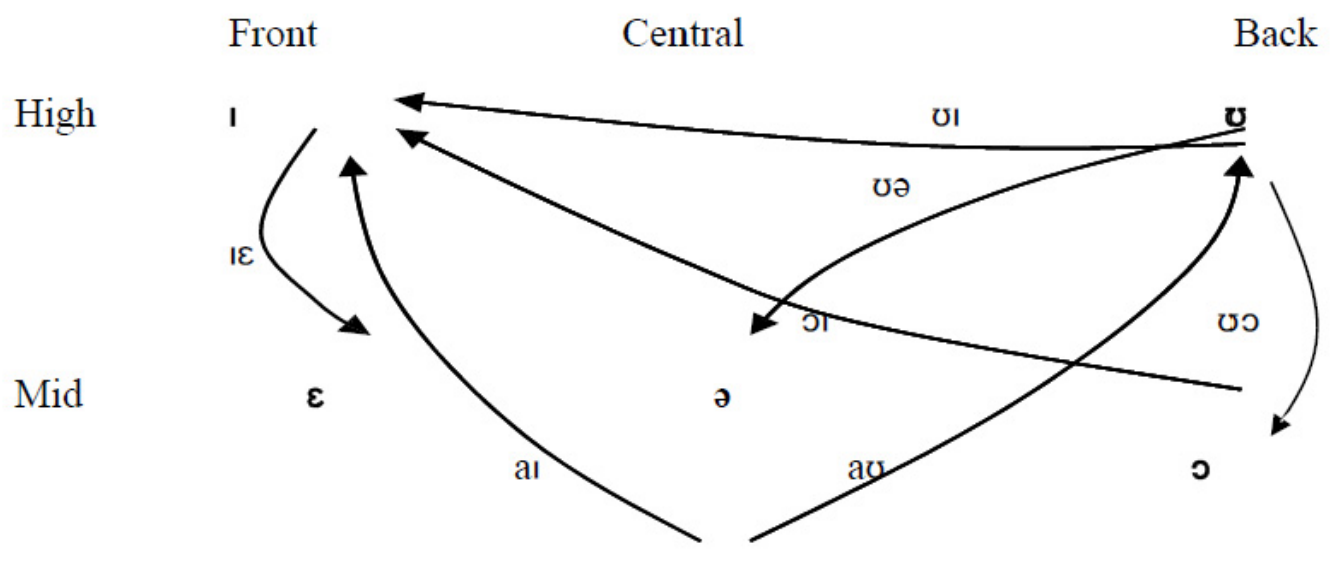

Figure 1. The Krokong Vowel Chart 


\section{Macrothink

3.2 Primary and Secondary Vowels

\begin{tabular}{|c|c|c|}
\hline \multicolumn{2}{|c|}{$\underline{\text { Bidayuh }}$} & $\underline{\text { Gloss }}$ \\
\hline (i)pit & [prt $]$ & small \\
\hline pat & [pat] & four \\
\hline pe' & [pe?] & girl \\
\hline po' & [po?] & place a bet \\
\hline put & [put] & an expression to show falling down \\
\hline piet & [pict] & to fold \\
\hline pait & [part] & send through someone \\
\hline paut & [pavt] & grab or hold on to \\
\hline poi & [рэг $]$ & an expression to show swinging \\
\hline (o)pui & {$[\mathrm{puI}]$} & fire \\
\hline puat & [puat] & transport \\
\hline puot & {$[$ pujt $]$} & odour \\
\hline
\end{tabular}

3.3 Long Versus Short Vowels

The Jagoi Bidayuh employs long and short vowels like Japanese. Consider the examples below from the Krokong dialect:

$\underline{\text { Short }}$

ti' $[\mathrm{tI} ?]$

tas $[\operatorname{taf}]$

$\operatorname{kod}[\mathrm{kJd}]$ $\underline{\text { Long }}$

$\begin{array}{lll}\text { tii } & {[\mathrm{tr}: \mathrm{T}]} & \text { itchy } \\ \text { taas } & {\left[\mathrm{ta}: \int\right]} & \text { ironwood } \\ \text { kood } & {[\mathrm{kJ}: \mathrm{d}]} & \text { taste funny }\end{array}$

\section{Morpheme Structure Constraints of the Krokong Dialect}

A native speaker of any language is somehow aware that certain sequences of sounds or a combination of sounds are not permissible in his or her language. Wolfram and Johnson (1988) observed that human languages usually have certain allowable groupings of sounds that can occur together to form words. Proponents of the structuralist view of linguistics described this boundaries governing the combination of sounds in a language as phonotactics while their generativists counterpart coined this same phenomenon as morpheme structure constraints (MSC) (Ohala \& Jaeger, 1986). However, in the definition of MSC, there are two 
kinds of constraints namely sequential constraints and segmental constraints. For the purpose of this paper, suffice to say that phonotactics or MSC's are rules that govern the way phonemes are arranged in a morpheme or a word (van der Hulst \& Ritter, 1999) and ascertained the phoneme inventory of the language. These rules can either be universal or language specific.

Sequential constraints are such that they express the restrictions on the combination of segments in a morpheme. For example, we can make derivations of 5 words by combining four phonemes $/ \mathrm{b} /, / \mathrm{a} /, / \mathrm{t} /$, and $/ \mathrm{R} /$ in Bidayuh.

$\begin{array}{lll}\text { aat } & \text { /Ra:t/ } & \text { root } \\ \text { baat } & \text { /ba?at/ } & \text { boundary } \\ \text { bata } & \text { /bata } & \text { brick } \\ \text { taa } & / \text { ta:?/ } & \text { guess } \\ \text { baat } & \text { /ba:t/ } & \text { heavv }\end{array}$

It is no accident that instances like $* / \mathrm{bta} /, * / \mathrm{tba} /, * / \mathrm{Pbat} /$, and $* / \mathrm{bta} /$ do not exist in the lexicon of Bidayuh. There are constraints that filter such words from being generated. In the above example, no consonant clusters can begin a word or a syllable in the language. Such constraints can be captured through the formalisation of MSC's. However, as I have pointed out earlier, these constraints are sometimes language specific. Consonant clusters are certainly permissible in English in words such as

'school', 'blue' and 'scrambling'. Nonetheless, it is safe to make an assumption that no sequence of five consonants can begin a word in any language. Thus, it is a universal MSC.

Segmental constraints, on the other hand, are those constraints which provide us with the set of possible phonemes in a language. For example, there are no laterals $/ 1 /$ or trills $/ \mathrm{r} /$ in Bidayuh. This can be stated as a rule by using the following segment structure constraint:

If: $\quad(-$ syllabic $)$

then: (-liquid)

In the above example, we have just stated some facts about Bidayuh which have been captured in a formalization given by an MSC. In fact, there are two other ways through which we can capture facts like the above. To begin with, what we have just seen is called the 'If-Then' condition. Secondly, we have the 'positive conditions' followed by the most infrequently used, the 'negative conditions'.

To further elaborate what an if-then condition in MSC's is like, we can state that in Bidayuh, no more than two consonants may begin a word (\#). The sequential constraints will further state that if the first segment is $/ \mathrm{t} /$, then it must be followed by $/ \mathrm{r} /$. This may be formally stated as follows:
If:
$\#(-$ syll $)$
( - syll )
( - syll )
(i.e. consonants) 
Then: + ant

- voi

- son

(i.e. voiceless alveolar stop)

+ cor

+ voi

(i.e. tap or flap)

An example of the formalization of a positive condition is the earlier example given of Bidayuh where no consonant clusters (two consonants occur one after the other) may appear in initial position:

If: $\quad$ \#

Then: ( + syllabic )

That is why when Bidayuh speakers encounter consonant clusters, they will insert a vowel in between the two consonants. For example, the word 'school' will be pronounced as 'sechool'

Subsequently, we utilize the negative conditions, which state what may not occur in a given morpheme or combination of morphemes. For example, a negative condition for Bidayuh vowels would say that a vowel with the features high-mid and front ( - back ) and ( +high ) may not include the feature +round. This means that there is no high front rounded vowel $/ y /$ in Bidayuh which a language like French has.

All these constraints are not ordered in any way when they are being applied. They are passive rules and do not change segments. What they do is simply act as filters. The MSC's as proposed by the generative phonologists are used to present a simple and an economical way of capturing these phenomenon of language (Hyman, 1975).

Do such constraints reflect some kind of reality in the mind of the speakers? Studies, such as the ones conducted by Fromkin (1973) on spoonerism, seem to suggest that there is a psychological reality. Errors in speech or 'slips of tongue' are predictable and they conform to the phenomena captured by MSC's. The most popular among al recorded cases of spoonerisms is the "queer old dean" instead of 'dear old queen'. 'Queer' and 'dean' are not only permissible words but they are in fact existing words of the English lexicon.

What we will never produce as a speech error are words like 'rquee' or 'dnea' as in 'Rquee old dnea'. English speakers intuitively know that those two words sound 'un- English' and hence are unacceptable. Thus, we can make predictions about what kinds of errors are possible given the constraints of English on the sequencing of phonemes to form words and morphemes.

What relevance do MSC's have to an applied linguist? How useful is it for a linguistic student in learning more about the Bidayuh? It is appropriate to mention the task of a language scientist has when it comes to describing a language, specifically in the case of the Bidayuh language, where there might be those whose native language may not be Bidayuh. Take for example, native speakers of Spanish who enrol in English classes. In their native tongue, consonant clusters like/sk/,/sp/, and /st/ are not permissible as initial clusters in a word. Therefore, whenever these students encounter clusters like the above, he/she will insert the vowel /e/ in front of them. As a result, we will surely hear words like 'eschool' instead of 'school', 'espanish' instead of 'spanish', 'estudent' instead of 'student'. With this kind of knowledge, the teacher is at an advantage because he/she will have an explanation for the 
problem and hence will be better prepared to remedy it. That is much better than having nothing to work with when in situations such as the above.

Likewise in Bidayuh, many non-native speakers may generalize certain formalization of rules not found in the Bidayuh language and misrepresent it as to make the final outcome pointless. Take for example when a non-native speaker of Bidayuh who assume that the consonant clusters of $/ \mathrm{kl} /$ exist in Bidayuh and goes on to transcribe $/ \mathrm{klas} /$ as one of the words found in the language. In actual fact, many older generation native Bidayuh speakers cannot articulate $/ \mathrm{k} /$ followed by an $/ 1 /$ because consonant clusters are not allowed in word initial position in Bidayuh. Most Bidayuh speakers would pronounce the word as [kJraf] instead. However, this and other similar prominent Bidayuh phonemes are fast disappearing among many younger speakers of Bidayuh at the time of this writing because they have a conception that these pronunciations are indicative of low educational and socio-economic status. The stigma attached to this perception may have strongly influenced many new generation Bidayuh speakers to support work on standardizing the language.

\section{To standardize or not to Standardize}

Natural languages generally exist in many different forms and varieties as they undergo changes through time. Language change occurs due to both internal and external influences (Östman\& Verschueren, 2011) and these changes are realized in all the linguistic features of the language. Changes can manifest within the sound patterns, the grammatical structures as well as affecting the semantic forms of the language. When speakers of a language are separated far enough to alienate one from the other, changes to speech and language patterns vary from one group to another based on rates and type of changes that occur. These variances can be explained in terms of influencing factors, both internal and external. As a result, different forms of the language exist side by side as dialects or sub-dialect like the Bidayuh language and its varieties highlighted here.

There comes a time when speakers of a language deem it necessary to be able to have a common form in order to communicate more effectively with one another without hindrances that usually occur when attempting to converse across dialects. This view is often reinforced by socio-political reasons such as unity and nationalism. Other reasons are more reputable such as keeping the language alive for posterity. As such, standardization and the teaching of the language in schools are among the top recommendations being deliberated. Language standardization is often viewed as giving priority to one form of a language and propagating its widespread use among speakers of its diverse varieties. Lane (2015) argued that any language standardization process has unintended consequences and these concerns should be addressed delicately.

Among the negative consequences of standardizing a language is the fear of losing socio-cultural and political status by speakers of the non-standard variety as well as the danger of making the other varieties to be neglected and consequently die out among the speakers. The issue of language death has been studied by many researchers (Krauss, 1992; Nettle \& Romaine, 2000; Sallabank, 2010; Sutherland, 2003) and it is a matter of great concern that varieties of Bidayuh like the Krokong dialect may face extinction if effort to 
preserve and propagate it among new generation of speakers is neglected to make way for a more dominant variety. According the Department of Statistics of Malaysia (DESM) (2016), there are 31.7 million people of all races in the country which include the three major races of Malays, Chinese and Indians contributing to most of the population. The rest are minority groups like the Bidayuhs, Ibans, Kadazans and Dusuns. These are predominantly found on the island provinces of Sabah, Sarawak and Labuan with a combined population of almost $20 \%$ of the total population (DESM, 2016). In the last census carried out, the Bidayuhs made up of about $8 \%$ of the total 2.42 million people living in Sarawak (DESM, 2011) which is about 194,000 people. With a five percent annual increase in population as reported by the DESM (2016), there are now approximately 200,000 Bidayuhs residing in the state and speaking the 25 varieties as reported by Rensch et al. (2012). This essentially means each sub-dialect has approximately more or less than 8000 speakers each which any linguists would know is not nearly enough to maintain the language in the long run. With standardization and other causes of language loss, the danger facing many of the smaller sub-varieties is real.

To prevent this from happening, a thorough study has to be done to find out how many dialects of Bidayuh are really out there. A careful analysis as to the boundaries between each sub-dialect has to be determined and this requires a team of experts who have to be well-versed in their ability as linguists. With the latest technology at their disposal, these linguists can then begin to properly classify and describe the different varieties so that they can be recorded and preserved. The outcome should be able to help determine how the standardization process of the Bidayuh language can begin to take shape.

\section{Conclusion}

The intricacies of language require all language scientists to be thorough and methodical in doing their analyses. Though complete but still not an exhaustive account of the phonetics and phonology of the Krokong dialect illustrated the argument here. The need is even more urgent when there is a lot of on-going effort to preserve the Bidayuh language by many interested parties from within the community as well as from outside

The intricacies of language require all language scientists to be thorough and methodical in doing their analyses. Though complete but still not an exhaustive account of the phonetics and phonology of the Krokong dialect illustrated the argument here. The need is even more urgent when there is a lot of on-going effort to preserve the Bidayuh language by many interested parties from within the community as well as from outside.

\section{References}

van der Hulst, H., \& Ritter, N. A. (1999) The syllable: Views and facts . New York, NY: Mouton de Gruyter, (Chapter 3).

Chang, P. F. (2002). History of Bidayuh in Kuching Division Sarawak. Kuching, Malaysia: Sarawak Press Sdn. Bhd.

Court, C. (1967). Some areal features of Məntu Land Dayak. Oceanic Linguistics, 6, 46-50. 
MI Macrothink 1 Institute

https://doi.org/10.2307/3622924

Garellek, M. (2013). Production and perception of glottal stops. (Unpublished doctoral dissertation). University of California, Los Angeles. California, USA. http://www.phonetics.ucla.edu/voiceproject/Publications/Garellek_2013_dissertation.pdf

Östman, J., \& Verschueren, J. (2011). Pragmatics in practice: Handbook of pragmatics. Amsterdam, Holland: John Benjamins Publishing Company. (Chapter 1). https://doi.org/10.1075/hoph.9

Hudson, A. B. (1970). A note on Selako: Malayic Dayak and Land Dayak languages in Western Borneo. Sarawak Museum Journal, 18(36-37), 301-318.

Hyman, L. (1975). Phonology: Theory and analysis. New York, NY: Holt, Rinehart and Winston.

Krauss, M. (1992). The world's languages in crisis. Language, 68, 4-10. Kroeger, P. R. (1994). The dialects of Biatah. https://doi.org/10.1353/lan.1992.0075

Ladefoged, P., \& Maddieson, I. (1996). The Sounds of the World's Languages. Oxford, UK: Blackwell.

Lane, P. (2015). Minority language standardisation and the role of users. Language Policy, 14, 263-283. https://doi.org/10.1007/s10993-014-9342-y

Moseley, C. (Ed.). (2009). UNESCO Atlas of the world's languages in danger of disappearing. Retrieved from http://www.unesco.org/culture/ich/index.php?pg=00206

Nettle, D., \& Romaine, S. (2000). Vanishing voices: The extinction of the world's languages. New York, NY: Oxford University Press.

Ohala, J. J., \& Jaeger, J. J. (1986). Experimental phonology. Orlando, FL: Academic Press. https://doi.org/10.1017/S0952675700000622

Rensch, C. M. (2006). Nasality in Bidayuh phonology. Kuching, Malaysia: Dayak Bidayuh National Association.

Rensch, C. R. (2008). Rhythm in Bidayuh. Studies in Philippine Languages and Cultures, 19, 84-91.

Rensch, C. R., Rensch, C. M., Jonas Noeb \& Robert Sulis Ridu (2006). The Bidayuh language: Yesterday, today and tomorrow. Kuching, Malaysia: Dayak Bidayuh National Association.

Sallabank, J. (2010). Language endangerment: Problems and solutions. Retrieved from http://www.gla.ac.uk/media/media_141050_en.pdf

Sutherland, W. J. (2003). Parallel extinction risk and global distribution of languages and species. Nature, 423, 276-279. https://doi.org/10.1038/nature01607

Collins, J. (1993). Language and oral traditions in Borneo: Borneo Research Council 


\section{Macrothink

proceedings series. Williamsburg, VA: Borneo Research Council.

Wolfram, W., \& Johnson, R. (1988). Phonological analysis: Focus on American English. Washington, DC: Harcourt Brace Jovanovich, Inc.

\section{Copyright Disclaimer}

Copyright reserved by the author(s).

This article is an open-access article distributed under the terms and conditions of the Creative Commons Attribution license (http://creativecommons.org/licenses/by/3.0/). 